\title{
PRÓBA USYSTEMATYZOWANIA POLSKIEJ TERMINOLOGII KOSMONOMASTYCZNEJ
}

Słow a tematyczne: kosmonomastyka, termin, terminologia kosmonomastyczna, kosmonim

Przystępując do próby uporządkowania polskiej terminologii kosmonomastycznej, warto sięgnąć do encyklopedii „Polskie nazwy własne” (dalej: PNW), gdzie przedstawiono historię systematyki terminologii onomastycznej oraz tendencje występujące w tworzeniu nowej terminologii (por. PNW, s. 77-78). Chodzi przede wszystkim o dwie przeciwstawne dążności: do stosowania terminów rodzimych i do stosowania terminów obcych. Jak wiadomo, polska terminologia onomastyczna jest mieszana: obecne są w niej terminy rodzime i obce, co więcej, często używane są wymiennie. Autorzy PNW ${ }^{1}$, powołując się na Ewę Rzetelską-Feleszko (1993, s. 217-222), postulują „utrzymanie tej dwoistości w odniesieniu do obcych terminów już utrwalonych w nomenklaturze polskiej”, nie zalecają zastępowania terminów rodzimych obcymi, jednak w przypadku nowych dziedzin badań onomastycznych ,można zaakceptować obcą nazwę, jeśli wyrazy im pokrewne znane są językowi polskiemu" (PNW, s. 77-78). Wydaje się, że jest to bardzo ważna dyrektywa w zakresie tworzenia nowych terminów onomastycznych.

Kosmonomastyka ${ }^{2}$ jest niewątpliwie nową dziedziną badań onomastycznych. Można ją zdefiniować jako dział onomastyki, który zajmuje się gromadzeniem, analizą i klasyfikacją nazw własnych obiektów znajdujących się w kosmosie ${ }^{3}$.

Od razu należy zaznaczyć, że PNW nie odnosi się właściwie w żadnym aspekcie do kosmonomastyki ${ }^{4}$. Z uwagi na to, że jest to nowy dział onomastyki, mamy

\footnotetext{
${ }^{1}$ Rozdział PNW dotyczący kierunków i metodologii badań oraz terminologii napisała Zofia Kaleta.

${ }^{2}$ Terminu tego po raz pierwszy użyła Ewa Jakus-Borkowa (2004).

${ }^{3}$ Ważne, żeby nie zawężać zakresu kosmonomastyki do nazw obiektów Układu Słonecznego, bo wiele obiektów mających nazwy własne znajduje się poza naszym układem planetarnym.

${ }^{4}$ Jedyna wzmianka, która pośrednio odnosi się do tego działu, dotyczy nazw gwiazd w kontekście nazwania nowej dziedziny badań onomastycznych (PNW, s. 78).
} 
do czynienia jedynie z kilkoma pracami, w których pojawia się terminologia kosmonomastyczna. Wydaje się, że pierwszym opracowaniem, w którym pojawiają się tego typu terminy, jest artykuł Jadwigi Waniakowej (2003a). Występują w nim jednak tylko dwa terminy: kosmonim 'nazwa własna obiektu kosmicznego' i astronim 'nazwa własna gwiazdy' (Waniakowa, 2003a, s. 225, 228)5. Rok później ukazała się monografia Ewy Jakus-Borkowej (2004), w której jest już sporo terminów z zakresu kosmonomastyki. Autorka była tak dobra, że udostępniła listę tychże terminów ${ }^{6}$, którą tu w oryginale przytaczam:

kosmonomastyka/astronomastyka/kosmonimika/astronimika

kosmonimialastronimia

kosmonim/astronim/nazwa kosmiczna

chrematonomastyka kosmiczna

chrematonimia kosmiczna

chrematonim kosmiczny/chrematokosmonimy (pl.)

kosmiczny chrematonim globalny

kosmonimia ludowa

kosmonim ludowy/ludowa nazwa kosmiczna

kosmonim globalny

kosmonim oficjalny/kosmonim urzędowy/kosmonim standaryzowany

kosmonim nieoficjalny

kosmiczny obiekt realny — nazwa własna kosmicznego obiektu realnego

kosmiczna projekcja/projekcja kosmiczna — nazwa własna kosmicznej projekcji "kosmiczna geografia"

toponimia kosmiczna/mikrotoponimia kosmiczna/astrotoponimia

kosmotoponimia/kosmomikrotoponimia

toponim kosmiczny/mikrotoponim kosmiczny/astrotoponim

selenonim

selenonimia

okazjonalizmy kosmiczne

toponimia ziemska

Na podstawie analizy powyższych terminów można sformułować kilka wniosków. Autorka preferuje terminologię obcego pochodzenia, co jest niewątpliwie trafne z uwagi na przynajmniej dwa czynniki: kosmonomastyka jest nowym działem onomastyki, zatem jej terminologia dopiero się tworzy. Poza tym terminy te

\footnotetext{
${ }^{5}$ Autorka jednak nie podaje definicji tych terminów, wynikają one z kontekstu.

${ }^{6}$ Listę tę, za zgodą Autorki, przekazała mi pod koniec 2017 roku prof. Barbara Czopek-Kopciuch, która jednocześnie zobowiązała mnie do zajęcia się terminologią kosmonomastyczną. Niniejszy tekst jest zatem wynikiem wykonania tego zadania.
} 
powstały głównie w oparciu o terminologię astronomiczną pochodzenia obcego, ale utrwaloną już w języku polskim. Widoczne jest, że Ewa Jakus-Borkowa stosuje obocznie kilka terminów na określenie tego samego pojęcia, np. kosmonomastyka/astronomastyka/kosmonimika/astronimika jako 'dział onomastyki zajmujący się nazwami własnymi obiektów znajdujących się w kosmosie', kosmonim/ astronim/nazwa kosmiczna 'nazwa własna obiektu znajdującego się w kosmosie'. Wydaje się, że należałoby wybrać tylko niektóre z nich, bowiem zbyt duża synonimia w terminologii nie jest zjawiskiem pożądanym, ponieważ może prowadzić do nieporozumień. Widać także, że autorka precyzyjnie oddziela nazwy działów onomastyki od zbiorów poszczególnych nazw własnych, np. kosmonomastyka jako nazwa działu onomastyki i kosmonimia jako zbiór kosmonimów, czyli nazw własnych obiektów w kosmosie. Takie podejście również trzeba uznać za słuszne, bowiem terminologia powinna być precyzyjna i jednoznaczna. Ponadto można zauważyć hierarchię użytej przez autorkę terminologii: są obecne terminy ogólne i terminy szczegółowe 7 . Przykładem terminu ogólnego może być kosmonim 'nazwa własna obiektu znajdującego się w kosmosie', podczas gdy terminami szczegółowymi są takie terminy, jak kosmonim ludowy/ludowa nazwa kosmiczna, kosmonim globalny, kosmonim oficjalny/kosmonim urzędowy/kosmonim standaryzowany, kosmonim nieoficjalny, odnoszące się do poszczególnych klas nazw własnych. Wobec tego np. kosmonim ludowy to 'ludowa nazwa własna obiektu znajdującego się w kosmosie', a kosmonim oficjalny to 'oficjalnie obowiązująca nazwa własna obiektu znajdującego się w kosmosie’. Z pewnością hierarchiczność terminologii jest rozwiązaniem bardzo dobrym, bo spełnia funkcję porządkującą.

Kolejną publikacją, w której występują terminy bliskie kosmonomastycznym, jest artykuł Jadwigi Waniakowej i Wacława Waniaka (2007). Niestety pojawiają się w tym tekście tylko dwa takie terminy. Pierwszy to chrematonimia astronomiczna `ogół nazw własnych odnoszących się do instrumentów badawczych, metod obserwacji i redukcji danych, projektów badawczych, instytucji astronomicznych oraz do oprogramowania, którym posługują się astronomowie', drugi to chrematonim astronomiczny 'nazwa własna odnosząca się do instrumentów badawczych, metod obserwacji i redukcji danych, projektów badawczych, instytucji astronomicznych oraz do oprogramowania, którym posługują się astronomowie' (por. Waniakowa, Waniak, 2007, s. 145, 148). Autorzy zastrzegają, że nie używają terminu chrematonimia kosmiczna, proponowanego przez Ewę Jakus-Borkową (2004), ponieważ sądzą, że omawiane przez nich chrematonimy nie odnoszą się tylko do kosmosu, ale do astronomii w ogóle (Waniakowa, Waniak, 2007, s. 145).

7 Terminy ogólne nazywają ogólne pojęcia, zaś terminy szczegółowe, zwane też nomenami, nazywają pojęcia specyficzne, które obejmują tylko część obiektów danej klasy ogólnej; za: Waniakowa $(2003$ b, s. 15, 18), tam też inna literatura na ten temat. 
Jak widać, lista dotychczas używanych terminów kosmonomastycznych jest dość krótka. Charakterystyczne, że znakomita większość z nich ma pochodzenie obce. Wynika to stąd, że zwykle terminologia astronomiczna, która jest podstawą tychże terminów, jest także pochodzenia obcego. Można przy tym zauważyć, że terminy pochodzenia obcego są krótsze od synonimów opartych na słownictwie rodzimym, por. kosmonim ludowy/ludowa nazwa kosmiczna. Oba terminy w tej parze są hybrydalne (zawierają elementy rodzime i obce), ponieważ w kosmonomastyce bardzo trudno zupełnie ominąć wyrazy pochodzenia obcego ze względu na wspomnianą obcość terminologii astronomicznej.

Budując system terminologiczny jakiejś dziedziny, należy pamiętać o zasadach tworzenia terminów. Omawia je szczegółowo Irena Bajerowa (1973, s. $127-$ 138), proponując na koniec ich brzmienie, optymalny porządek i hierarchię ${ }^{8}$. Uszeregowanie to wygląda następująco:

1) zasada poprawności: termin powinien być zgodny z tendencjami rozwojowymi języka, z jego normami gramatycznymi i ortograficznymi;

2) zasada powszechności: te same terminy w tym samym znaczeniu powinny być stosowane we wszystkich dziedzinach wiedzy naukowej i technicznej;

3) zasada zrozumiałości etymologicznej: struktura terminu powinna być przejrzysta i zrozumiała;

4) zasada logiczności: termin powinien spełniać swoje zadanie, czyli uwydatniać istotne składniki i właściwości nazywanego pojęcia;

5) zasada jednoznaczności: termin powinien odnosić się tylko do jednego pojęcia;

6) zasada zwięzłości: termin powinien być jak najbardziej zwięzły;

7) zasada systematyczności9: terminom odnoszącym się do pojęć równorzędnych powinien odpowiadać termin nadrzędny, odnoszący się do pojęcia bezpośrednio nadrzędnego ${ }^{10}$;

8) zasada pokrewności: termin powinien być pokrewny słowotwórczo terminom odnoszącym się do pokrewnych pojęć;

9) zasada łatwości: termin powinien być operatywny fonetycznie.

Kolejność na powyższej liście wskazuje, które cechy i zasady są najważniejsze, a które mniej istotne przy tworzeniu nowych terminów oraz przy badaniu struktury terminów już istniejących.

Jeśli przyjrzymy się używanym do tej pory terminom kosmonomastycznym, biorąc pod uwagę wymienione zasady tworzenia terminologii, zauważymy, że nie wszystkie z nich są utworzone prawidłowo. Nie miejsce tu, by analizować

\footnotetext{
${ }^{8}$ Autorka czerpie z wcześniejszych prac na ten temat oraz z Polskiej Normy. Jej rozważania dotyczą terminów technicznych, ale można je odnieść także do terminologii naukowej.

${ }^{9}$ Preferowałabym tu sformułowanie: zasada systemowości.

${ }^{10}$ Można tu zastosować wspomniany wyżej podział na terminy ogólne i terminy szczegółowe.
} 
pod względem zgodności z zasadami każdy przytoczony wyżej termin. Lepiej skupić się na systemowym podejściu do całości terminologii kosmonomastycznej, wskazując najważniejsze jej cechy, które są nieodzowne do tego, aby była ona klarowna i spójna, zarówno pod względem językowym, jak i merytorycznym.

Jak wspomniano, wydaje się, że polska terminologia kosmonomastyczna powinna się opierać na słownictwie pochodzenia obcego, ponieważ terminologia astronomiczna, która stanowi jej podstawę, ma przeważnie rodowód obcy. Należy zatem tworzyć terminy oparte na istniejących terminach astronomicznych. Warto dbać o precyzyjność i jednoznaczność tejże terminologii, więc trzeba zrezygnować z synonimii. Najlepiej uczynić to, wybierając taki z możliwych terminów, który spełnia większość wymienionych zasad tworzenia terminów. Tworzone terminy powinny być więc przede wszystkim zwięzłe, mieć przejrzystą strukturę oraz spełniać zasadę logiczności. W ten sposób terminologia ta będzie tworzyła spójny system.

Na początek trzeba wyraźnie rozdzielić dwa zasadnicze terminy, mianowicie użyty tu już kilkakrotnie termin kosmonomastyka oraz termin kosmonimia.

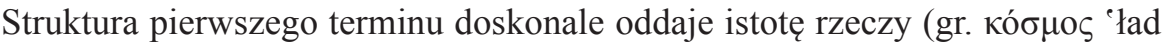
wszechświata, wszechświat, niebo’ + onomastyka), jest to wszak ‘dział onomastyki, który zajmuje się gromadzeniem, analizą i klasyfikacją nazw własnych obiektów znajdujących się w kosmosie'. Drugi z terminów — kosmonimia — to 'zbiór kosmonimów" ${ }^{11}$. Konsekwencje wyboru formy kosmonomastyka są następujące: terminy astronomastyka, kosmonimika, astronimika mogłyby wyjść z użycia, bo synonimia $\mathrm{w}$ terminologii jest zbędna, a poza tym niektóre $\mathrm{z}$ tych terminów nie są nawet synonimami, np. termin astronomastyka nie jest synonimiczny do ter-

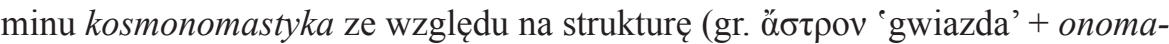
styka); to samo odnosi się do terminu astronimika. Następnie warto podkreślić, że kosmonimia nie jest synonimem astronimii, której znaczenie — zgodnie ze

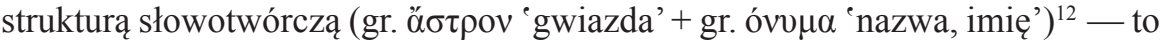
'zbiór astronimów'13. Dalsza konsekwencja to stwierdzenie, że kosmonim nie jest synonimem astronimu, natomiast jest jego hiperonimem. Wydaje się także, że należałoby usunąć wymieniony termin nazwa kosmiczna jako mało precyzyjny w swojej strukturze i niejednoznaczny. Bardziej precyzyjny byłby termin *nazwa

${ }^{11}$ Kosmonim natomiast można zdefiniować następująco: 'nazwa własna obiektu znajdującego się w kosmosie'.

${ }^{12}$ Można się zastanawiać, dlaczego wobec tego mamy do czynienia z terminem astronomia zamiast *kosmonomia, ale odpowiedź jest prosta. Otóż złożenie astronomia jest poświadczone już w grece (gr. $\alpha \sigma \rho \tau o v o \mu i ́ \alpha)$. W ciągu dziejów stopniowo rozszerzało i uściślało swoje znaczenie, aż stało się terminem.

${ }^{13}$ Astronim to 'nazwa własna gwiazdy'. Nazw gwiazd funkcjonuje w astronomii bardzo dużo, np.: Antares, Syriusz, Wega. 
obiektu kosmicznego, lecz byłby on zbyt długi. Stąd — mimo że termin nazwa kosmiczna od dawna występuje w terminologii kosmonomastycznej ${ }^{14}$ - można by z niego zrezygnować na rzecz kosmonimu. Wracając do terminu kosmonimia, warto jeszcze raz podkreślić, że jest to termin ogólny w stosunku do takich terminów szczegółowych, jak kosmonimia naukowa i kosmonimia ludowa. Przy tym kosmonim jest terminem ogólnym wobec takich terminów szczegółowych, jak kosmonim oficjalny, kosmonim ludowy itd. Mając na celu uporządkowanie terminologii kosmonomastycznej, można przyjąć, że z pary kosmonim ludowy/ ludowa nazwa kosmiczna należałoby pozostawić w użyciu tylko termin kosmonim ludowy, ponieważ lepiej pasuje do systemu oraz jest bardziej zwięzły. Z triady kosmonim oficjalny/kosmonim urzędowy/kosmonim standaryzowany, należałoby z tych samych względów wybrać termin kosmonim oficjalny. Opozycją do niego w systemie terminologicznym byłby kosmonim nieoficjalny. Terminy nazwa własna kosmicznego obiektu realnego oraz nazwa własna kosmicznej projekcji są za mało konkretne i zbyt długie, zatem mogłyby nie wejść do systemu terminologicznego ${ }^{15}$. Wydaje się, że można pominąć całą triadę toponimia kosmiczna/mikrotoponimia kosmicznalastrotoponimia. Powody są następujące: termin toponimia kosmiczna, rozumiany jako zbiór nazw własnych konkretnych miejsc w kosmosie, nie jest odpowiedni, ponieważ w kosmosie nie ma stałych miejsc, wszystko jest w nieustannym ruchu, więc nie można mówić o nazwach własnych jakichś miejsc. To samo odnosi się do mikrotoponimii kosmicznej. Termin astrotoponimia jest na razie potencjalny, stworzony na wyrost, ponieważ twory na „powierzchni” Słońca, czyli w fotosferze (np. plamy słoneczne), lub w wyższych warstwach atmosfery Słońca (np. protuberancje, koronalne wyrzuty masy) nie są stałe w czasie i nie otrzymały nazw własnych. Podobnie jest $\mathrm{z}$ innymi gwiazdami ${ }^{16}$, których wygląd znamy głównie z badań interferometrycznych. Niewykluczone, że postęp w zakresie tych badań doprowadzi do odkrycia tworów na tyle trwałych, że otrzymają one swoje nazwy.

Z tych samych powodów nie powinno się stosować pary terminów kosmotoponimia/kosmomikrotoponimia, jak również triady toponim kosmiczny/mikrotoponim kosmiczny/astrotoponim. Wydaje się także, że można pominąć termin okazjonalizm kosmiczny, ponieważ nie jest konkretny.

\footnotetext{
14 Występuje on obocznie do kosmonimu już w 1983 roku w OS (s. 117).

${ }^{15}$ Podobnie do kosmonomastycznego systemu terminologicznego nie należy termin geografia kosmiczna.

${ }^{16}$ Definicja gwiazdy w ujęciu astronomicznym jest niezwykle rozczłonkowana (głównie z uwagi na wielość parametrów i liczne odniesienia do poszczególnych rodzajów gwiazd), jednak jej ośrodkiem jest stwierdzenie, że gwiazda jest kulą gazową, świecącą dzięki własnym zasobom energii (SSA s. v.).
} 
Można natomiast pozostawić termin toponimia ziemska, gdyż odnosi się do toponimii Ziemi jako planety, podobnie jak jesteśmy w stanie mówić o toponimii Marsa czy Wenus (o czym niżej).

Bardzo trafnymi terminami, które powinny być nadal stosowane, są terminy: selenonim 'nazwa własna księżyca' (por. gr. $\sigma \varepsilon \lambda \hat{v \eta \eta ~ ' k s i e ̨ z ̇ y c ') ~ i ~ s e l e n o n i m i a ~}$ 'zbiór nazw własnych księżyców planet'. Są to terminy bardzo potrzebne, bo szereg planet ma księżyce, którym nadano nazwy. Za przykład mogą tu służyć księżyce Jowisza, jak Io, Europa, Ganimedes, Callisto, których nazwy w drodze transonimizacji przeszły z postaci mitologicznych związanych z Zeusem na ciała niebieskie (szerzej: Waniakowa, 2003a, s. 228). Przy okazji terminów kosmonomastycznych związanych z księżycami warto wspomnieć, że na Księżycu ziemskim zaobserwowano różne twory powierzchniowe, które nazwano, jak np. kratery: Planck, Kopernik, Skłodowska. Nazwy własne otrzymują też tereny na księżycach innych planet, np. na Ganimedzie, gdzie występuje duży ciemny obszar nazwany Gallileo Regio ${ }^{17}$. Nazwy te można objąć wspólnym terminem selenotoponimy, zatem selenotoponim to 'nazwa własna obszaru powierzchni księżyca', a selenotoponimia to zbiór takich nazw.

Osobne rozważania należą się przytoczonym terminom związanym z chrematonimią, jak: chrematonomastyka kosmiczna, chrematonimia kosmiczna, chrematonim kosmiczny/chrematokosmonimy (pl.) i kosmiczny chrematonim global$n y$. Należy do nich podejść bardzo ostrożnie. Jak wiadomo, same terminy chrematonim - jako 'nazwa własna wytworu jednostkowego lub seryjnego pracy ludzkiej'18 — oraz chrematonimia — 'zbiór chrematonimów' — nie odnoszą się do nazw własnych obiektów, które znajdują się w sposób naturalny w kosmosie. Obiekty takie, jeśli są w przestrzeni kosmicznej, zostały tam wprowadzone przez człowieka. Co więcej, istnieje cały szereg obiektów - wytworów człowieka które służą do badań kosmosu, ale się w kosmosie nie znajdują (np. większość teleskopów). Są to urządzenia specjalistyczne, ale też różnego rodzaju międzynarodowe organizacje astronomiczne i całe sieci badawcze. Odnoszą się zatem do całej astronomii. W związku z tym wydaje się, że najlepszym rozwiązaniem byłoby potraktowanie tych nazw własnych jako przedmiotu badań chrematonomastyki astronomicznej, a same nazwy własne, odnoszące się do takich obiektów, można by nazwać chrematonimami astronomicznymi (por. wyżej). Co więcej, tak określona chrematonomastyka astronomiczna nie byłaby częścią kosmonomastyki, a osobnym działem chrematonomastyki. Przy takim założeniu wymienione terminy nie należałyby do terminologii kosmonomastycznej.

\footnotetext{
${ }^{17}$ Warto pamiętać, że cztery największe księżyce Jowisza odkrył Galileusz (1564-1642).

18 Jest to najogólniejsza definicja zaczerpnięta z PNW (s. 343).
} 
Po wytyczeniu granic kosmonomastyki i kosmonimii oraz analizie stosowanych już terminów kosmonomastycznych (z których część została przyjęta) należy zająć się ,inwentarzem” klas obiektów znajdujących się w kosmosie i mających nazwy własne w celu wyodrębnienia terminów odnoszących się do kosmonomastyki. Aby zaproponować kolejne terminy kosmonomastyczne, trzeba wymienić klasy obiektów kosmicznych nazwanych indywidualnie przez człowieka w ciągu dziejów.

Gwiazdy na niebie układają się w gwiazdozbiory, inaczej konstelacje (: łac. cōnstellātiō). Są to 'fragmenty sfery niebieskiej wyróżnione w celu przybliżonej orientacji na niebie' (SSA s. v.). Gwiazdozbiory mają swoje nazwy, np.: Andromeda, Orion, Mała Niedźwiedzica (Ursa Minor). Każda z tych nazw to konstelacjonim, a zbiór takich nazw to konstelacjonimia. Astronomowie wyodrębniają gromady gwiazd (ang. star clusters), czyli grupy gwiazd, które oprócz wspólnego miejsca w naszej Galaktyce mają jednakowy ruch, wiek i wspólne pochodzenie (SSA s. v.). Niektóre z tych gromad mają (prócz oznaczeń katalogowych) swoje nazwy, jak Plejady, Hiady, Żłóbek (ang. Beehive Cluster). Nazwy takie można by określić

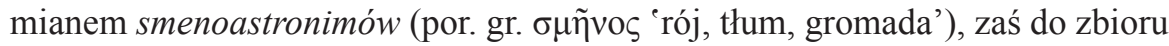
takich nazw odnosiłby się termin smenoastronimia ${ }^{19}$.

Oprócz gwiazd i księżyca (księżyców), o których była mowa wyżej, na niebie widzimy planety, które mają swoje nazwy, jak Merkury, Wenus, Mars. Wydaje się, że pojedynczą nazwę własną planety można określić mianem planetonimu, a planetonimia byłaby zbiorem planetonimów. Na powierzchni planet w drodze obserwacji astronomicznych wyodrębnia się różne obszary. Otrzymują one nazwy. Każdą z nich można określić mianem planetotoponimu, innymi słowy, planetotoponim to 'nazwa własna obszaru powierzchni planet', zaś zbiór takich nazw to planetotoponimia. Nazw takich jest całkiem sporo. Można tu przytoczyć dla przykładu kilka toponimów z Marsa: Góra Olimp (Olympus Mons) ${ }^{20}$, Syrtis Major Planum ${ }^{21}$, Planum Boreum ${ }^{22}$.

Niewidoczne na niebie gołym okiem są planetoidy ${ }^{23}$. One również mają nazwy (np. Ceres, Pallas, Westa). Termin planetoidonim odnosiłby się do każdej z nazw własnych planetoid, a planetoidonimia to byłby ‘zbiór planetoidonimów’. W polskiej terminologii astronomicznej funkcjonuje także synonim terminu planetoida.

${ }_{19}$ Pewnym argumentem za takim rozwiązaniem jest określenie gromady gwiazd we współczes-

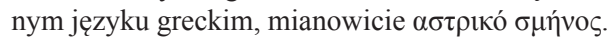

${ }^{20} \mathrm{~W}$ rzeczywistości jest to wygasły wulkan.

${ }^{21}$ Jest to największy ciemny obszar Marsa. Początkowo był uważany za morze, obecnie wiadomo, że jest to obszar wulkaniczny z polami lawy. Jego nazwa wywodzi się od zatoki Morza Śródziemnego - Wielkiej Syrty.

${ }^{22}$ Nazwa północnego płaskowyżu Marsa.

${ }^{23}$ Są to skaliste, mniejsze od planet, ciała w Układzie Słonecznym, krążące wokół Słońca po orbitach leżących na ogół między orbitami Marsa i Jowisza (SSA s. v. planetoida). 
Jest to wzięty z języka angielskiego termin asteroida (por. ang. asteroid) ${ }^{24}$. Jednak $\mathrm{w}$ trosce o jednoznaczność terminologii kosmonomastycznej nie należy tworzyć terminów synonimicznych, typu *asteroidonim, *asteroidonimia.

Ciałami niebieskimi, które niekiedy są widoczne gołym okiem, są komety ${ }^{25}$. Mają one również swoje nazwy, np.: kometa Halleya (1P/Halley), kometa Enckego (2P/Encke), kometa Tuttle'a (8P/Tuttle). Nazwy te związane są zwykle z nazwiskami ich odkrywców. Właściwym terminem dla tego rodzaju nazwy własnej wydaje się kometonim, natomiast kometonimia to 'zbiór nazw własnych komet'.

Pewien problem z punktu widzenia terminologii kosmonomastycznej mogą stanowić nazwy własne rojów meteorów, jak Arietydy, Orionidy, Perseidy. Nazwy ich wywodzą się od nazw gwiazdozbiorów, w granicach których są radianty tych rojów, czyli miejsca na niebie, skąd pozornie wylatują meteory, zatem tutaj odpowiednio jest to gwiazdozbiór Barana (Aries), Oriona i Perseusza. Rój meteorów (ang. meteor shower) nie ma nazwy jednowyrazowej, trudno zatem utworzyć prawidłowe i zwięzłe terminy kosmonomastyczne w tym zakresie. Racjonalnym wyjściem w tym wypadku wydaje się zastosowanie peryfrazy: nazwy własne rojów meteorów. Można by też wprowadzić jednowyrazowy termin oparty na leksemach greckich, mianowicie brochometeoronimia (por.

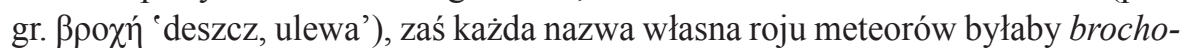
meteoronimem ${ }^{26}$.

Do obiektów kosmicznych, które mają nazwy własne, należą także galakty$\mathrm{ki}^{27}$. Przykładami takich nazw mogą być: Galaktyka Andromedy (ang. Andromeda Galaxy), Czarne Oko (ang. Black Eye Galaxy), Wielki Obłok Magellana (ang. Large Magellanic Cloud), Sombrero (ang. Sombrero Galaxy). Nasza Galaktyka (pisana wielką literą) z powodu innego niż pozostałych galaktyk jej widoku z Ziemi (ze względu na to, że nasz Układ Słoneczny do niej należy) jest nazywana także Drogą Mleczna (ang. Milky Way). Nazwy własne galaktyk można określić mianem galaktonimów, ich zbiór określałby natomiast termin galaktonimia. Astronomowie wyróżniają również gromady galaktyk. Są to wielkie grupy galaktyk, które tworzą

${ }^{24} \mathrm{~W}$ języku angielskim funkcjonują też terminy planetoid i minor planets, ale nie są one zbyt często używane. Astronomowie, którzy posługują się w swojej dziedzinie wyłącznie językiem angielskim, zdecydowanie preferują termin asteroid.

${ }^{25}$ Kometa to 'drobne lodowo-pyłowe ciało Układu Słonecznego poruszające się wokół Słońca po orbicie eliptycznej lub parabolicznej; kometa charakteryzuje się specyficznym wyglądem: wokół jasnego jądra rozciąga się mglista otoczka, a z niej, odsłonecznie, jest wywiewany warkocz kometarny' (SSA s. v.).

${ }^{26}$ Pewnym argumentem za takim rozwiązaniem jest określenie roju meteorów we współczesnym

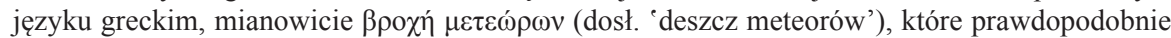
stanowi kalkę angielskiego terminu meteor shower.

${ }^{27}$ Galaktyka to największy, występujący we wszechświecie, związany grawitacyjnie system gwiazd (SSA s. v.). 
związane grawitacyjnie układy. Niektóre z nich mają nazwy własne, które pochodzą najczęściej od gwiazdozbiorów, w granicach których obserwuje się je na niebie, lub od charakterystycznego wyglądu, np.: Gromada Panny (ang. Virgo Cluster), Lokalna Gromada Galaktyk (ang. Local Group), Gromada Pocisk (ang. Bullet Cluster). Każdą z takich nazw można określić mianem smenogalaktoni-

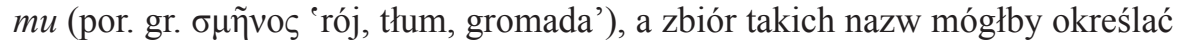
termin smenogalaktonimia ${ }^{28}$.

Kolejny typ obiektów kosmicznych, z których pewne otrzymały nazwy własne, to mgławice (łac. nebulae $)^{29}$. Można podać następujące przykłady takich nazw: Krab, Kocie Oko, Mrówka. Każdą z tych nazw można określić mianem nebulonimu, zaś zbiór takich nazw to nebulonimia.

Astronomowie dzięki coraz lepszym przyrządom odkrywają coraz dalsze obiekty kosmiczne, które tworzą nieznane do niedawna typy. Do takich obiektów można zaliczyć kwazary ${ }^{30}$. Mają one ścisłe oznaczenia katalogowe, które są w zasadzie ich nazwami własnymi, jednak część z nich ma prócz tego inne, powszechnie przez astronomów używane, nazwy własne, np.: Twin Quasar ${ }^{31}$, Krzyż Einsteina (ang. Einstein Cross), Koniczyna (ang. Cloverleaf). Nazwy tego typu są związane ze swoistym wyglądem obrazów tychże kwazarów ${ }^{32}$. Stąd wydaje się właściwe utworzenie terminu kwazaronim w znaczeniu ‘nazwa własna kwazaru’ oraz terminu kwazaronimia 'zbiór nazw własnych kwazarów'.

Szereg obiektów w kosmosie ma nazwy, które w istocie są ich oznaczeniami katalogowymi, zawierającymi głównie litery (będące na ogół skrótami pełnych nazw katalogów) i liczby (wskazujące zwykle kolejną pozycję w katalogu lub położenie na niebie). Jak się wydaje, zasady takiego oznaczania, a tym samym tworzenia tego rodzaju nazw, nie są obecnie istotne z onomastycznego punktu widzenia. W przyszłości być może będą stanowiły przedmiot badań kosmonomastycznych, chociaż będzie to wtedy z pewnością swego rodzaju wyzwanie dla badaczy. Do takich obiektów można zaliczyć brązowe karły, czarne dziury, polary, pulsary itd. Nawet jeśli kiedyś onomaści się nimi z jakichś przyczyn zainteresują,

${ }^{28}$ Pewnym argumentem za takim rozwiązaniem jest określenie gromady galaktyk we współ-

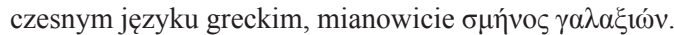

${ }^{29}$ Mgławica to dawniej ogólna nazwa obiektów kosmicznych o nieostrych konturach (z wyjątkiem komet). Obecnie termin ten obejmuje tylko zagęszczenia (obłoki) materii międzygwiazdowej (SSA s. v.).

${ }^{30}$ Są to obiekty gwiazdopodobne, które emitują fale radiowe. Są postrzegane fotograficznie jako gwiazdy, ale o dużym przesunięciu widma ku czerwieni, typowym dla galaktyk lub znacznie większym (SSA s. v. kwazar).

${ }^{31} \mathrm{~W}$ języku polskim nie używa się nazwy własnej tego kwazaru. Stosuje się jedynie jego numer katalogowy.

${ }^{32} \mathrm{~W}$ istocie bowiem chodzi o obrazy kwazarów, jakie są tworzone przez soczewkowanie grawitacyjne. 
zawsze będą mogli stwierdzić, że badają nazwy własne tych obiektów bez stosowania specjalnych terminów z zakresu kosmonomastyki.

Zmierzając do konkluzji powyższych rozważań, należy zauważyć, że już wcześniej zostały stworzone zasady tworzenia terminologii naukowej. Ponadto trzeba stwierdzić, że w kilku publikacjach zastosowano w praktyce wiele terminów z zakresu kosmonomastyki. Duża część z nich jest zgodna z prawidłami tworzenia terminów. Zadaniem niniejszego artykułu była próba usystematyzowania tej terminologii. Zaproponowano rozdział między kosmonomastyką, jako działem onomastyki zajmującym się nazwami obiektów kosmicznych, a chrematonomastyką astronomiczną, jako działem chrematonomastyki dotyczącym nazw własnych wytworów człowieka, które służą do badań kosmosu. Dokonano również analizy istniejącej już terminologii pod kątem jej zgodności z zasadami tworzenia terminów, uściślono pewne terminy oraz zaproponowano wiele nowych. Przyjęto przy tym, że terminy kosmonomastyczne powinny być pochodzenia obcego, podobnie jak terminy astronomiczne, które są ich podstawą. W ten sposób wskazano wytyczne do ewentualnego tworzenia przyszłych terminów. Stwierdzono również, że nazwy niektórych obiektów kosmicznych ze względu na swoją strukturę nie są i prawdopodobnie nie będą przedmiotem zainteresowania onomastyki, więc nie jest konieczne tworzenie związanej z nimi terminologii kosmonomastycznej.

\section{LITERATURA}

Bajerowa, I. (1973). Językoznawca wobec tzw. zasad słowotwórstwa technicznego [A linguist confronted with the so-called principles of technical word formation]. Poradnik Językowy, 3, $127-138$.

Jakus-Borkowa, E. (2004). Polskie nazewnictwo kosmiczne [Polish Cosmic Nomenclature]. Opole: Uniwersytet Opolski.

OS = Vidoeski, B. i in. (red.). (1983). Osnoven sistem i terminologija na slovenskata onomastika. Osnovnaâ sistema i terminologiâ slavjanskoj onomastiki. Grundsystem und Terminologie der slawischen Onomastik. Skopje: Makedonska akademija na naukite i umetnostite.

PNW = Rzetelska-Feleszko, E. (red.). (1998). Polskie nazwy własne. Encyklopedia [Polish Proper Names. Encyclopedia]. Warszawa-Kraków: Towarzystwo Naukowe Warszawskie-Instytut Języka Polskiego PAN.

Rzetelska-Feleszko, E. (1993). Polska terminologia onomastyczna. Problematyka [Polish onomastic terminology. Problems]. Zeszyty Naukowe Uniwersytetu Gdańskiego. Prace Językoznawcze, $17-18,217-222$.

SSA = Królikowska-Sołtan, M., Kwast, T., Sołtan, A. i Sroczyńska-Kożuchowska, M. (red.). (1994). Stownik szkolny. Astronomia [School Dictionary. Astronomy]. Warszawa: WSiP.

Waniakowa, J. (2003a). Onimizacja i transonimizacja w nazewnictwie astronomicznym [Onymization and transonymization in astronomical onomastics]. Onomastica, 48, 225-238.

Waniakowa, J. (2003b). Polska naukowa terminologia astronomiczna [Polish Scientific Astronomical Terminology]. Kraków: Instytut Języka Polskiego PAN.

Waniakowa, J. i Waniak, W. (2007). Skrótowce stylizowane w chrematonimii astronomicznej [Stylized acronyms in astronomical chrematonymy]. LingVaria, 3, 145-153. 


\section{SUMMARY}

AN ATTEMPT TO SYSTEMATIZE POLISH COSMONOMASTIC TERMINOLOGY

The aim of the article is an attempt to systematize Polish cosmonomastic terminology. A separation was proposed between cosmonomastics as a part of onomastics dealing with the names of cosmic objects, and astronomical chrematonomastics as a part of chrematonomastics dealing with the names of human products that are used to research the cosmos. The existing terminology was analyzed from the point of view of the rules of creation of scientific terms. Moreover, certain terms were clarified and a number of new ones proposed. It was also assumed that cosmonomastic terms should be of foreign origin, like the astronomical terms on which they are based. Thus, guidelines for the possible formation of future cosmonomastic terms were suggested.

Keywords: cosmonomastics, term, cosmonomastic terminology, cosmonym 